\title{
GROTESQUES, CARICATURES AND THE CLEVER MICE AT PISTIROS
}

\author{
JAN BOUZEK, IVA ONDŘEJOVÁ
}

\begin{abstract}
The article discusses a selection of five particular pieces from the 27 sealings found at Pistiros in Bulgaria in 2012, most of them with two imprints, apparently attached to a document with a contract or a deal. Subjects represented on the seals discussed here show grotesques, caricatures and mice acting as humans. They reflect a specific anecdotic side of Greek art in its northern fringes expressed in grotesque, at the time of Philip II and Alexander the Great. Attached is a late $4^{\text {th }}$ century BC Attic pelike from Pistiros with similar caricature of Rhea and Kronos or the maenad with Dionysus, from the ca. $310 \mathrm{BC}$ destruction.
\end{abstract}

Keywords: seal imprints; pottery; Scythians; comic actors; Hermaphrodite; Kronos; Rhea; $5^{\text {th }}$ and $4^{\text {th }}$ century BC Greek art

The Czech-Bulgarian excavations at Pistiros brought already much of interest; ${ }^{1}$ for the dedication to our old friend and confrère several new items revealed there may represent a modest gift to his rounded birthday. The most interesting among the materials found in the last years at Pistiros is a hoard of miniature clay sealings, discovered in the Square B' 3, south-west of the bastion and near the eastern city wall. The sealings were lying on the bottom of a vaulted kiln (oven); the 27 items differ in various realistic and imaginary subjects and by the state of preservation (Gotzev, Petrova 2013a; 2013b).

The documents on a papyrus to which the sealings were originally attached by a cord or a ribbon were apparently hidden in the kiln in the moment of imminent danger and burnt together with the kiln by fire of the sacked city. The destruction of the kiln can be dated, as the other features destroyed around it, to ca. 310 BC (Bouzek 2013: 66-68), at a time of wars between the diadochs (cf. Nankov 2008; for the Pistiros chronology and history cf. Bouzek, Domaradzka 2013). This gives the date ante quem for the sealed documents of contracts or deals which were probably kept together inside a textile bag.

1 Of the six volumes of publication reports series, notably Pistiros V and the supplementary volume published as Studia Hercynia 17/1, 2013 give general survey of history and situation in the emporion. 
The kiln was destined for baking bread, not for pottery or other industrial activity (see Fig. 1), but near to it there was an atelier producing Thracian fibulae (Domaradzki 1996 and 2002) and a concentration of loom-weights (Bouzek 1996b: 118; 161-162), which has two possible explanations: either a small sanctuary (an especially sophisticated loomweight with dedication to Magna Mater and her fragmentary relief have been found at Pistiros, cf. Bouzek 2016a) or a textile production workshop.

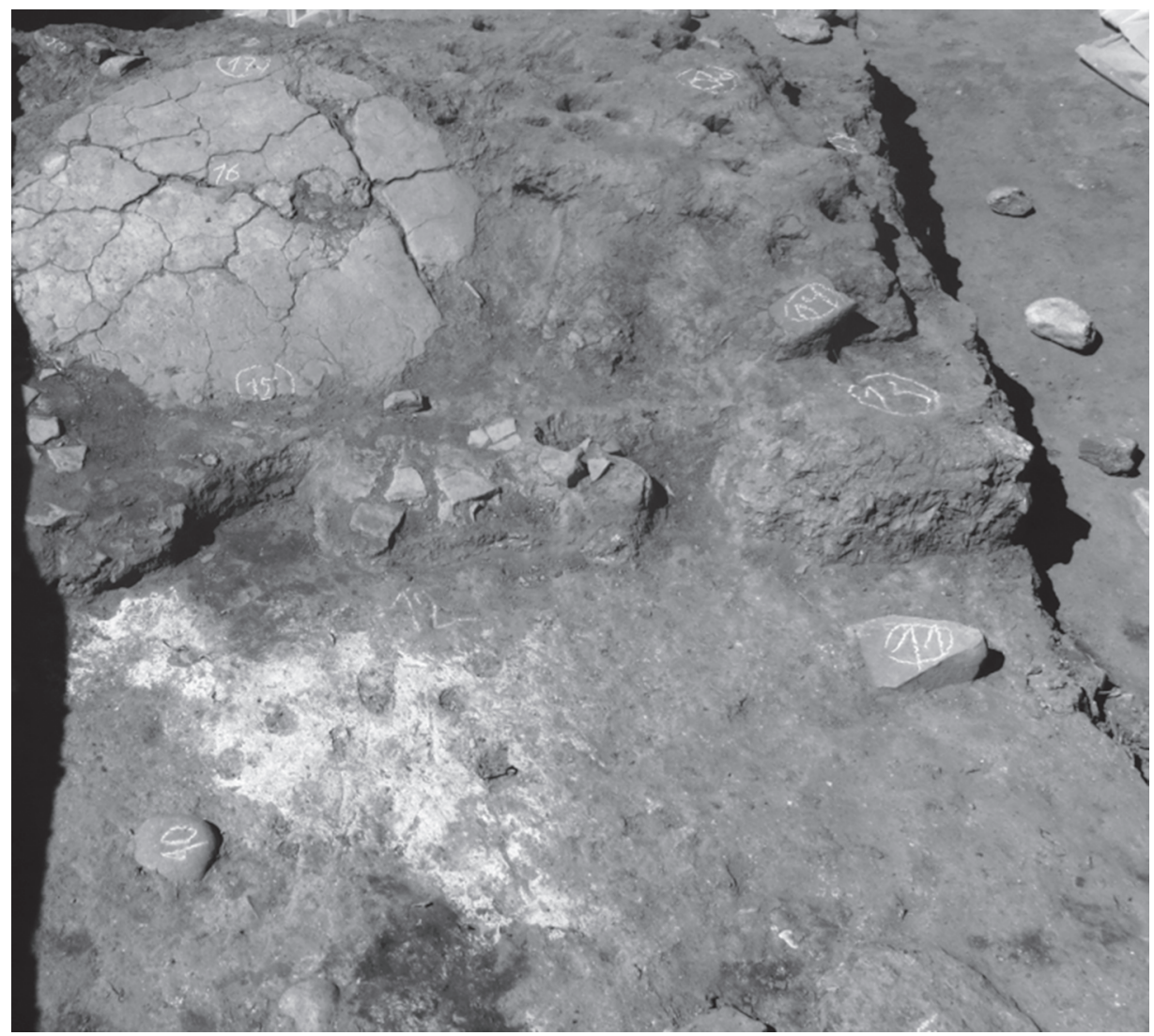

Fig. 1. Pistiros. Destruction of the kiln (oven) in Square B' 3, ca. 310 BC.

The burnt seal imprints were lying on the circular flat inner bottom of the kiln in the left upper corner of the picture. Note the circle of small holes on the right and lower sides of the photograph: they are traces of wattle and perhaps reed construction carrying the chapel of the kiln. Cf. Pistiros V, pl. 2.2.

Similar archives of seal imprints known as yet are all later, the sealings were mainly of dried clay (Delos, Pella) or of clay and bitumen (Seleucia) and have imprint on the obverse, while the reverse bears traces of an attachment (Boussac 1992 and 1993; Akamatis 2011: 69-70; Herbert 2003: 66; Stamboulidis 1992; for other cf. Plantzos 1999). The Delos archives were found in a burnt house, those in Pella in a burnt layer at the South portico of the agora (cf. also Avigad 1986; Gates 2003; Herbert 2003). Hellenistic sealings from NW Greece are discussed by Plantzos (1999). 
In Delos the rear side of the sealings bears traces of papyrus on which the sealing was stamped. After editing the document the papyrus was folded and fastened by one or more strings and then one or more clay balls were used to coat the strings. Almost all of the preserved sealings from emporion Pistiros have traces of cord, ribbon or textile bands on the reverse (single or double, crossed) below the images. In some cases, the textile material is a ribbon impressed by two parallel lines of this same band.

The sealing from Pella (Akamatis 2011: 105, fig. 3) and the sealing no. 20 from Pistiros (Gotzev, Petrova 2013b: no. 20, pl. 51) have a single imprint representing a woman's head en face. Both women have crowns and earrings with pendants. A woman's head with a crown of towers symbolizes Pella (Akamatis 2011: 70), the capital of the Macedonian empire.

For various reasons, the discussion of the complex is published as a series of several subsequent papers. One article on Dionysiac dancers discussing a group of seals closely reflecting monumental sculpture was published in Eirene (Bouzek, Ondřejová 2015) and another in a paper on the style and subject of the sealings in the frame of Black Sea iconography in Ancient West and East (Bouzek 2015). Here we discuss a particular group of caricatures and grotesque subjects. Boardman (1970: 230-232) gives a survey of Classical types of finger rings with their metallic bezel; in his group C (late $5^{\text {th }}-$ first half of $4^{\text {th }}$ century BC) grotesque subjects and monstra are common and our group is not much later. Added is one Attic red-figured pelike of similar air of grotesque, showing one of the aspects of life in the emporion. The population was literate, graffiti found on Attic Black Glazed and local sherds (among them on the only two Panathenaic amphorae found so far in Bulgaria) give Greek and Thracian names, male and female, dedication to deities, signing of property of the particular vessel (also by a woman), amount of contents on jars, even an abecedarium, and probably also voting ostraca (small rounded shards filled completely by one personal name). The degree of literacy can be compared with that of Seuthopolis studied by Nankov (2012; cf. for Pistiros Domaradzka 2013 with earlier publications quoted), but it started here one hundred years earlier.

\section{Two Scythian warriors (?)}

Sealing 4 discussed here first, is not fully preserved, it was impressed from oval to rectangular seal, probably on a ring. As against most of other sealings with two imprints placed together, thus belonging to documents of contracts closed by two partners, the present item bears, as it seems, only one clear imprint, showing two figures (Gotzev, Petrova 2013b: 195, pl. 46). Here Fig. 2, either an old and a young Scythian, or perhaps Heracles and Iolaos with Hydra (?) as suggested by Gotzev.

On the left there is standing youth in right profile, slightly bent forward, of the head remains visible ear, mouth, eye and short hairdo; in his right hand he holds two spears. In front of him a second standing male figure with Negroid-Satyr traits is bent even deeper forward, he holds probably also a spear and a bow (?) at the right hand edge of the preserved picture, but a mace is standing upright in front of him, supported by his bent knee. Behind his outstretched arm there are two wavy lines, read by A. Gotzev as remains of necks of Hydra, whose central part was situated further right and is not preserved. The lower part of both figures is much damaged, too. 


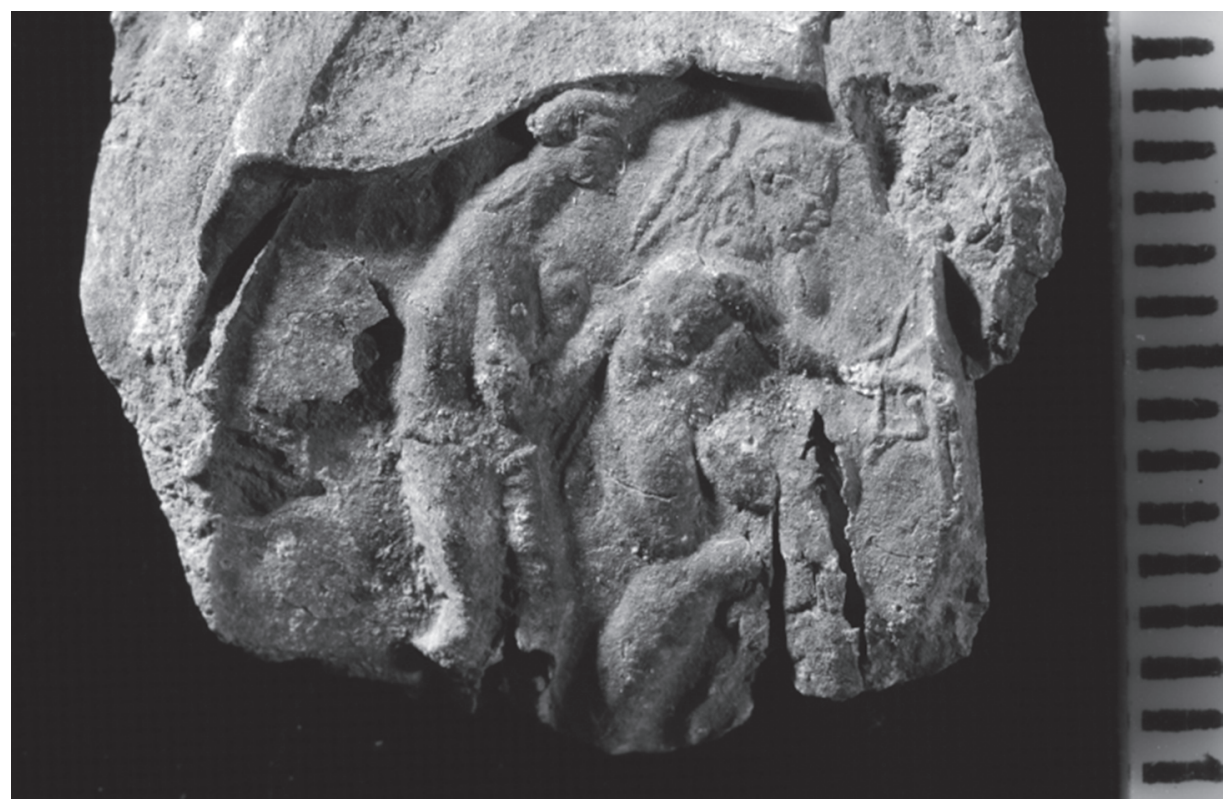

Fig. 2. Two warriors or Heracles and Iolaos with Hydra, sealing 4.

The rear side of the sealing is slightly concave, with traces of parallel thin threads of some light textile. Less fine clay than that of other sealings, brown to grey. W. 18, H. 18, Th. $4 \mathrm{~mm}$.

The strange face of the older man has parallels on sealing 9a (Gotzev, Petrova 2013b: 195, pl. 47) and of the Hermaphrodite on sealings 5 and 6 (Gotzev, Petrova 2013b: pl. 46) and 2a (Gotzev, Petrova 2013b: pl. 45). These faces may be called caricatures; this style reminds one of the North Thracian-Getic art (Bouzek 2005: 102-103), of the famous relief with battle scene from Jubilejnoe on the Taman peninsula (Bouzek 2003) and on the less sophisticated Greek Scythian toreutics (e.g. Rolle, Müller-Wille, Schietzel 1991: 366-369, Bratoljubskij kurgan).

From the pictures of Heracles and Iolaos registered in LIMC (Boardman [et al.] 1990: 34-41; Pipili 1990) there are no close parallels among the late $4^{\text {th }}$ century BC and Early Hellenistic representations. Heracles with Hydra, but without Iolaos, is represented on several Archaic and Classical gems: Richter 1968: 80, no. 230 (early $4^{\text {th }}$ century BC) and 196, no. 791 (Etruscan scarabaeus, ca. 500 BC); another scarabaeus in AGDS II: 48-49, no. 80 , pl. 22 dates from mid- $6^{\text {th }}$ century BC; another Classical gem with the subject is illustrated with Furtwängler 1896: 237, no. 6484.

\section{The Hermaphrodite sealing has similar face with pointed nose as those mentioned above:}

Sealing 5. Ecliptic field. Pistiros V, pl. 46, here Fig. 3. Hermaphrodite turned right, in three quarters view, dressed in a draped short chiton. Head strongly bent downwards, 
right arm bent at elbow, holding rolled cloak (?) or raised chiton to show his genital, left arm put on a rock. High hairdo with coif, a stream of hair falls on the back. Rear side flaked away. Deep fissure in the left upper part of the sealing. Only one seal impression preserved. Fine light grey clay. W. 14, H. $18 \mathrm{~mm}$.

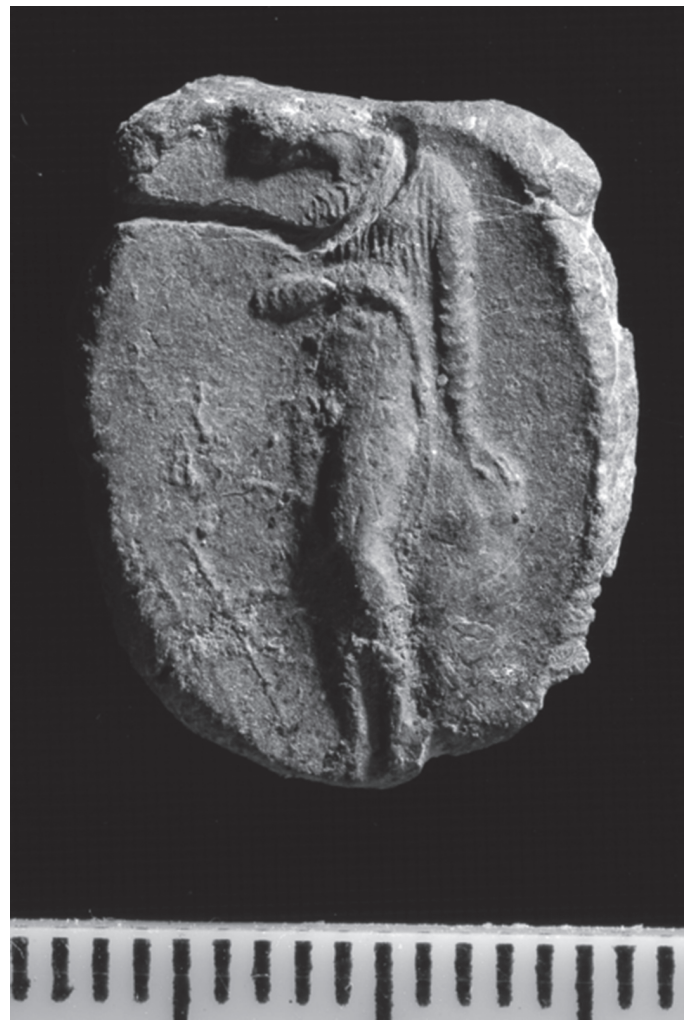

Fig. 3. Hermaphrodite, sealing 5.

Sealing 6 is impressed from the same seal as sealing 5. Pistiros V, pl. 46, here Fig. 4. Double sealed. Right-hand field: standing Hermaphrodite from the same seal as the preceding. In the left hand field a head of a lion and a sitting sphinx. The left-hand field was stamped later than the right field, part of it is missing. Rear side flaked off. W. 15, H. $21 \mathrm{~mm}$.

While large part of the seal imprints in the hoard followed the mainstream of $4^{\text {th }}$ century BC Greek art, the Hermaphrodite is a particular case, including the Archaistic drapery raised to show his small penis turned upwards. He has a long pointed nose and other comic traits, characteristic for the tendency towards caricature (cf. Ajoutian 1990, where there is no close parallel shown, but the first mention of his worship quoted). The Archaizing style is rare in $4^{\text {th }}$ century; the gesture of showing his genitals by raising his / her chiton has only later parallels (Ajoutian 1990: 270-272, no. 30ff.). Theophrast. Charact. 16 (The superstitious man), 10 mentions that Hermaphrodites should be venerated 


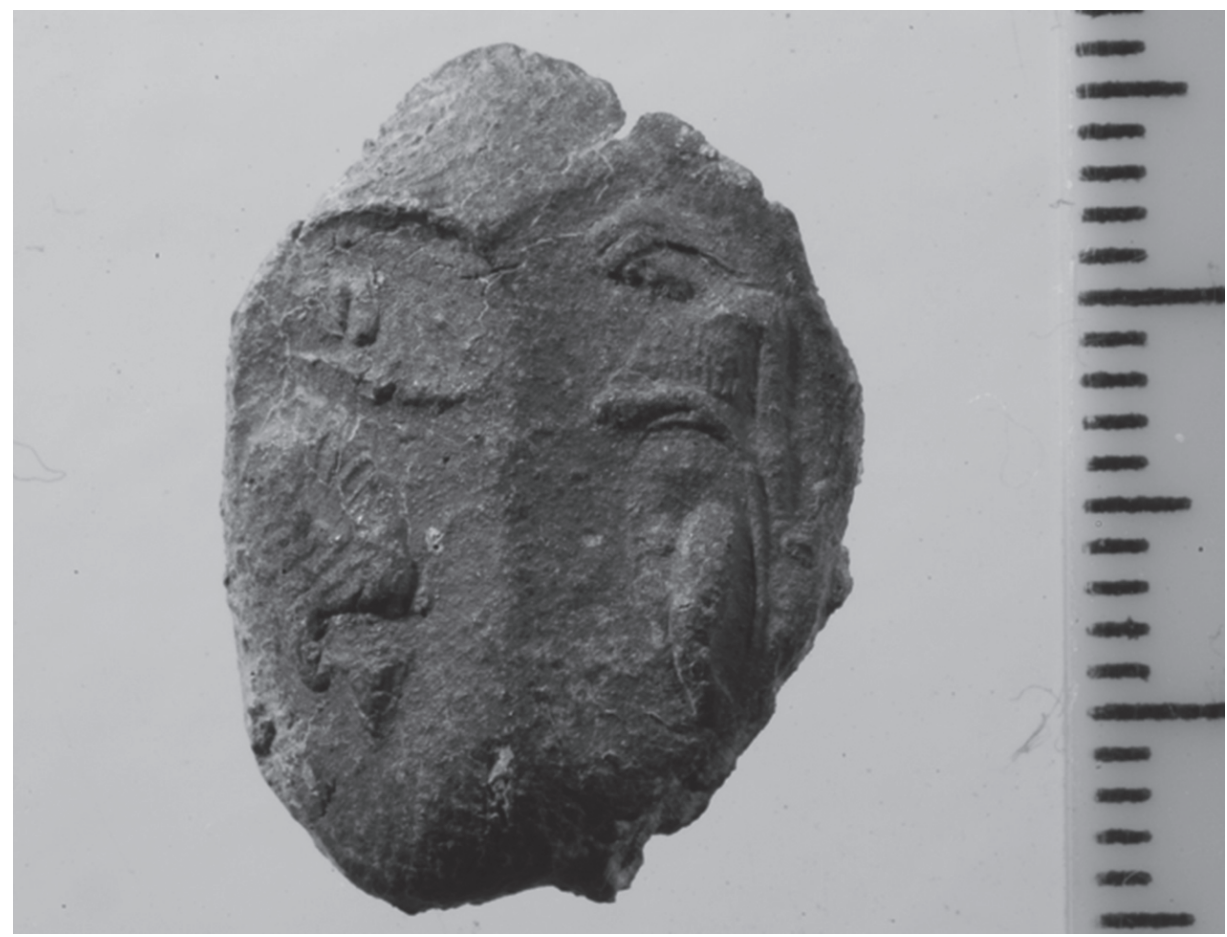

Fig. 4. Hermaphrodite, sealing $6 \mathrm{~b}$.

by garlands on the fourth day of every month. As the face with pointed nose is very similar to the group discussed above he might well be made by the same local gem engraver; it shows also similar taste.

Cf. standing statuary type of Hermaphrodite, with thyrsos and kantharos, Furtwängler 1900: 53 , no. 50, pl. 10 (4th century AD); AGDS IV: 162, no. 795, pl. 102: sitting Hermaphrodite rising his dress and admiring his erection, chalcedony ( $1^{\text {st }}$ century AD), cf. Furtwängler (1896: 350, no. 1241), cameo Boardman (1968: 100, no. 62); motif AGDS I/1: 343, no. 68, pl. 40. House of the Vettii. For the Archaizing drapery with deep folds cf. e.g. Boardman (1970: 292, no. 584; 293, no. 593 and 594).

\section{3.}

The field of grotesques includes also the left hand impression on Sealing 12 (here Fig. 5), the right imprint is by the seal of Penelope or dancer in cloak (Gotzev, Petrova 2013b: 196, pl. 48; Bouzek, Ondřejová 2015; $23 \times 18 \mathrm{~mm}$ ). Comic actor in nearly frontal view, his cloak thrown over his left shoulder, turns to right. He holds in his left hand hung along the body a stick, and in his outstretched right hand a round object, probably a mask. It resembles the bronze figurine of comic actor published already with commentary in Pistiros I by Lazov 1996 and Bouzek 1996a (here Fig. 6). The subject of comic actor 


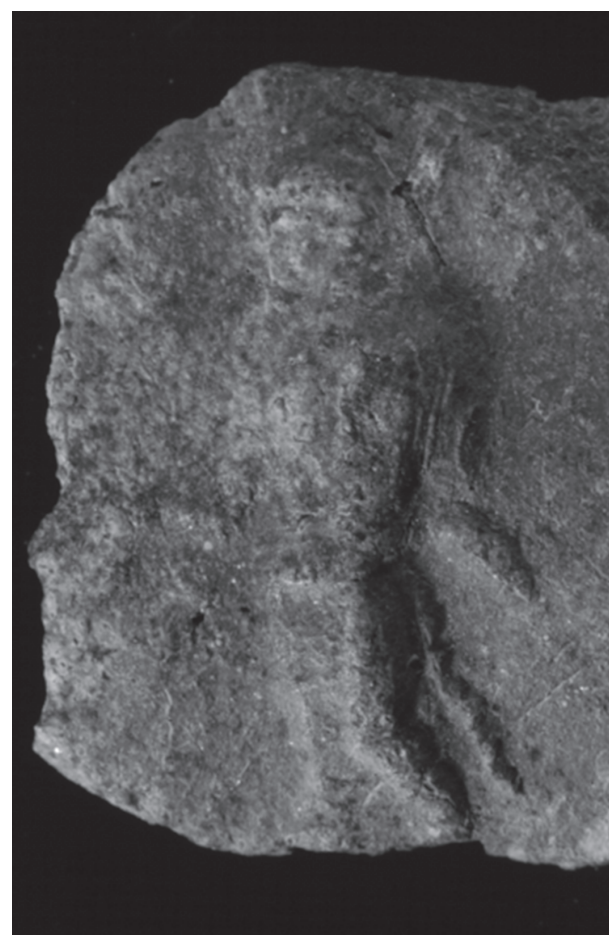

Fig. 5. Comic actor, sealing $12 \mathrm{~b}$.

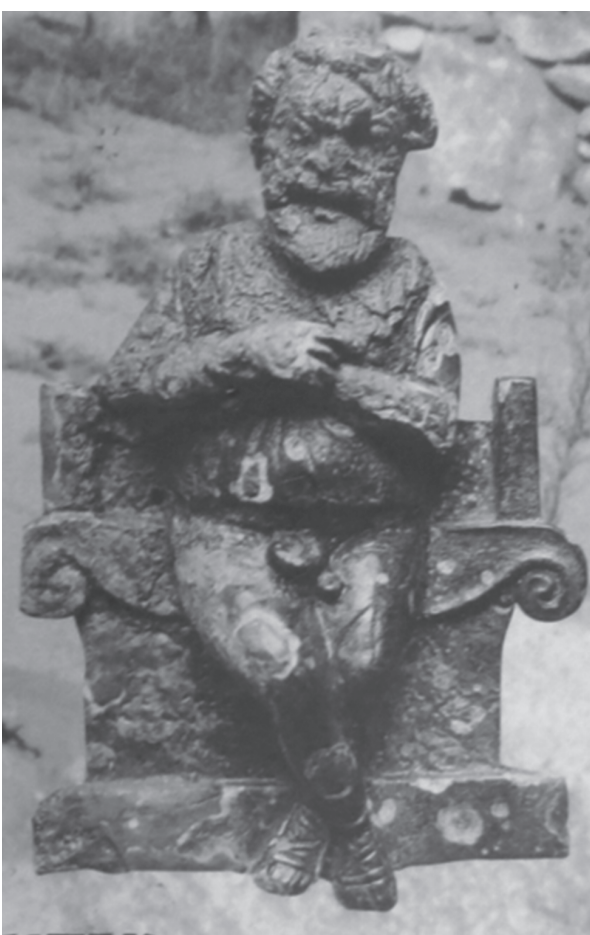

Fig. 6. Comic actor, bronze appliqué of a throne.

was popular among the $4^{\text {th }}$ to $3^{\text {rd }}$ century BC terracottas and also as thrones appliqués (cf. Lazov 1996).

Similar comic actors on gems are e.g. in Furtwängler 1900: 141, nos. 39-40, 42, 43, 49,50, pl. 28; the nearest to the Pistiros sealing is no. 51, with a stick in his right and a mask in his left hand; all dated Hellenistic to Early Roman period. Cf. also AGDS II: 139, no. 354, pl. 64 and 155, no. 407, pl. 72 ( $2^{\text {nd }}-1^{\text {st }}$ century BC), AGDS IV: 55-56, nos. 170-175, pl. 30-31; 108-110, nos. 453-459, pl. 74; 199, no. 988, pl. 132 ( $1^{\text {st }}$ century BC).

\section{Clever mice}

Sealing 1. Double stamped, both sealings stamped nearly on the same level (from the same angle), one reaching into another. Pistiros V, pl. 45, here Figs. 7-9. Right-hand field nearly circular. In the centre blacksmith's tongs, on the sides mice with astragals (knucklebones). Left hand field ellipsoid, naked male figure turned to right in three-quarter view, right arm bent at elbow, hand holding probably the apples of the Hesperides, over his left forearm hanging cloak. Head unclearly stamped, with helmet or special hairdo. Rear side flattened while sealing, imprint of narrow (17 mm wide) ribbon, underneath imprints of threads. Very fine, light brown clay. W. 25, H. 20, Th. $5 \mathrm{~mm}$. 


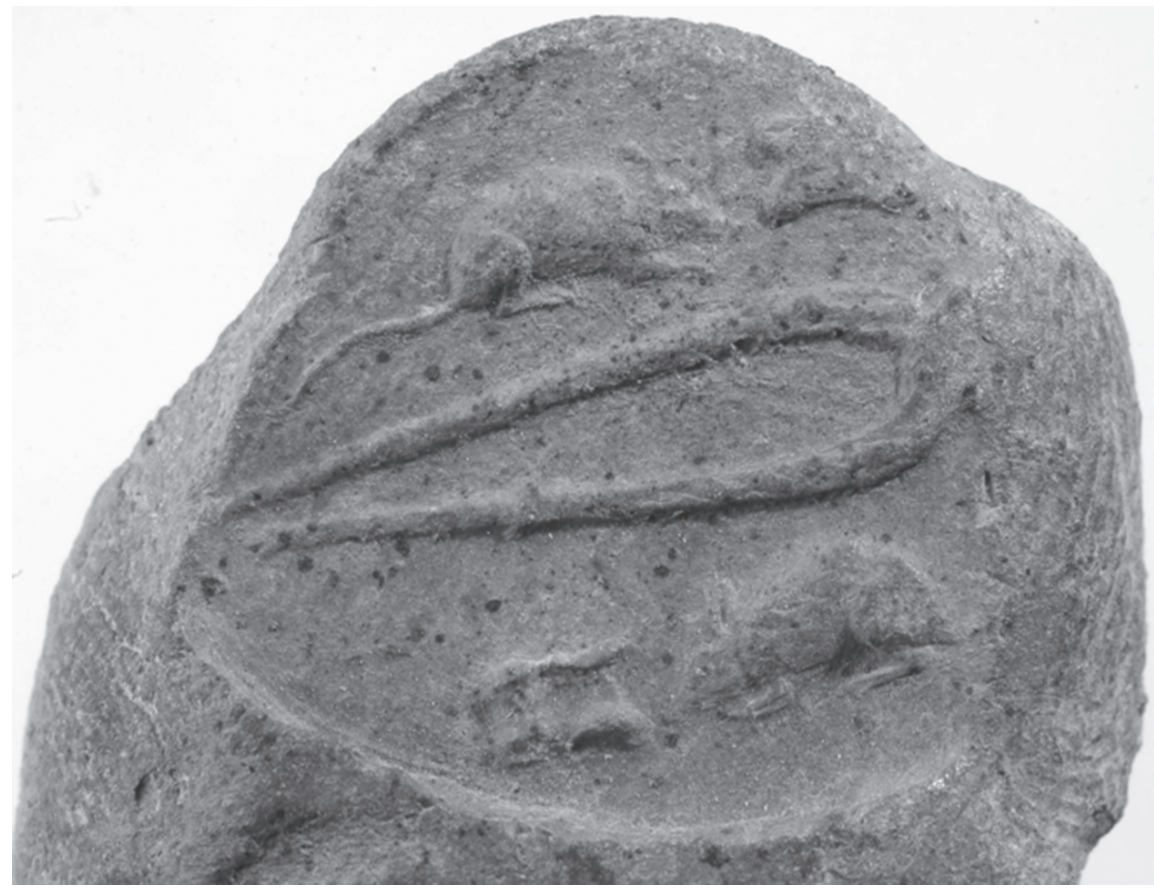

Fig. 7. Mice with astragals, sealing 1a.

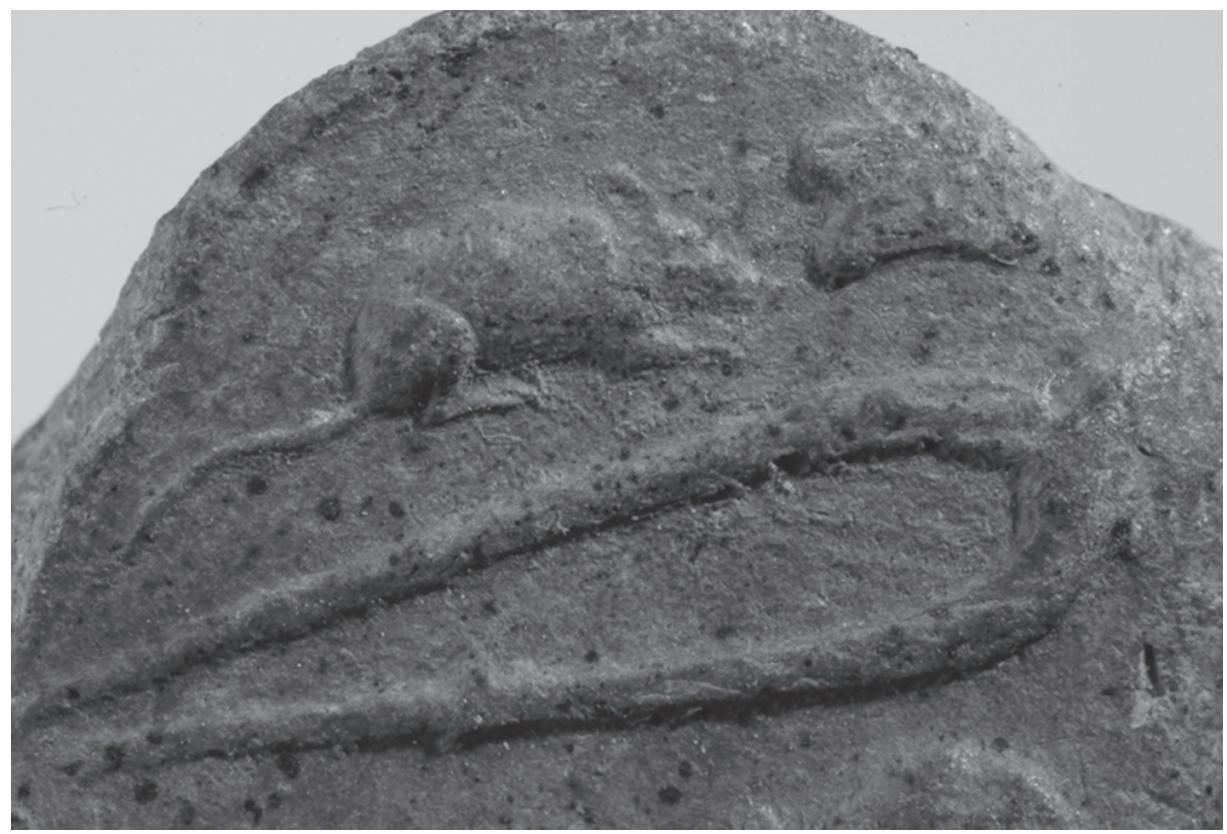

Fig. 8. Mice with astragals, sealing 1a. 


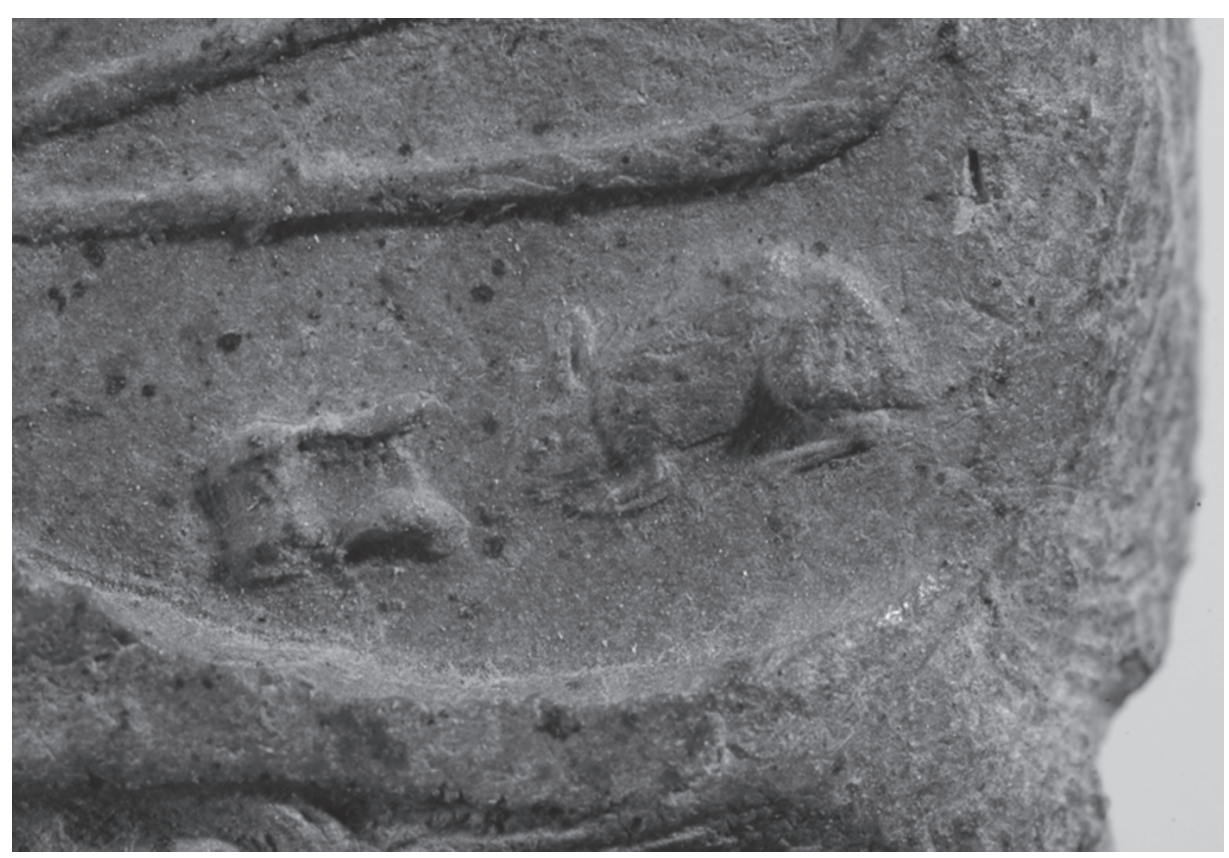

Fig. 9. Mice with astragals, sealing 1a.

The story of mice helping in astragal game reminds of one short story by William Saroyan On young man and a white mouse. The subject is unique, but maybe characteristic for the life at the margins of the world, with not highly respected moral values.

Pre-Roman mice on gems are rare. Similar is Boardman 1970: 315, no. 893 (= Furtwängler 1900: 59, no. 21, pl. 12), with other animals on polygonal chalcedony, in Graeco-Persian style as the dog on the loom-weights (Ondřejová 2007, here Fig. 10). Slender mouse with ears in mouth and column on gold ring bezel, Boardman 1970: 226, no. 751, is different in style. On Roman gems mice often appear as charioteers of chariots drawn by birds (Henig 2007: 140, no. 388, pl. 12, drawn by cocks), in other cases holding and eating nuts or cabbage (Platz-Horster 1987: 79, no. 141; Maaskant-Kleibrink 1978: 240, nos. 616-617, both nicolo; AGDS I/3: 45-56, no. 2373, pl. 213; 99, nos. 2751-2754, pl. 258-259, jasper, cornelian; AGDS II: 196-197, no. 555, pl. 95, jasper; AGDS IV: 237, no. 1231, pl. 167, glass, two rabbits drawing, mouse leading chariot; 237, nos. 1232-1237, pl. 167-168 with wreath, bones, ears, etc.; Platz-Horster 1987: 79, no. 141, mouse with nut, hexagonal gem, $3^{\text {rd }}$ century AD).

Astragals are rarely depicted on gems: Dioscuri playing with astragals are on the gem AGDS II: 72-73, no. 153, pl. 35; AGDS IV: 52, no. 154, pl. 29 with baby Heracles fighting snakes has four astragals in corners. Satyrs playing dice are depicted on AGDS IV: 37, nos. 76-77, pl. 21, Nike with dice on the gem Furtwängler 1900: 68, no. 27, pl. 14. 


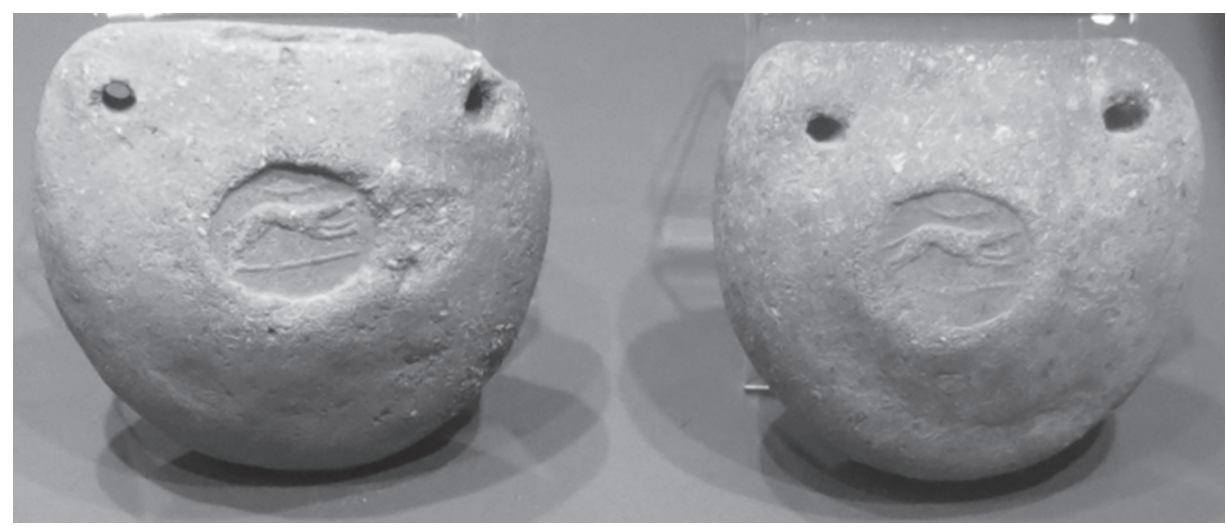

Fig. 10. Loom-weights with impressions: running dog.

5.

A late $4^{\text {th }}$ century BC pelike: Rhea offering Kronos to swallow stone instead of baby Zeus, supervised by Eros. H. ca. $18 \mathrm{~cm}$ (here Fig. 11). The pelike fits best into the late $4^{\text {th }}$ century (J. Boardman). ${ }^{2}$

The item comes from sector A north of the House No. 1, excavations G. Lazov, who kindly gave us the permission to reproduce it; it is composed from fragments coming from various deposits and finally fell into the ca. 310 BC destruction.

Though only sketched, well expressed are the surprise of Kronos (that large parcel I have to swallow!) and the decisive gesture of Rhea, supported from behind by a winged boy, probably Eros in his celestial function. The iconography of Kronos and Rhea as listed in LIMC (Serbeti 1992; Gury 1994) does not contain any similar caricature of the event with the exception of an earlier pelike in New York (Serbeti 1992: 143, no. 22 by the Nausikaa Painter, ca. 460-450 BC), but even here the dressed Kronos shows a higher level of dignity. The Pistiros pelike can be compared with the air of Aristophanes' comedies, notably his Birds (Ornithoi), with making fun of gods, though in none of his preserved plays the scene is known.

\section{The historical and cultural context of the artefacts}

Pistiros was founded in the $3^{\text {rd }}$ quarter of the $5^{\text {th }}$ century BC by the citizens of Thasos, Maroneia and Apollonia, who kept their citizenship, but as an autonomous body of emporitai closed a contract with Thracian kings (Velkov, Domaradzka 1996; Bouzek, Domaradzka 2013). The sophisticated fortification and water management are similar to those of Thasos and Amphipolis. The hippodamean division into plots was kept until

2 John Boardman kindly corrected the dating. He also suggested a possibility of explaining the scene as the maenad with Dionysus. 


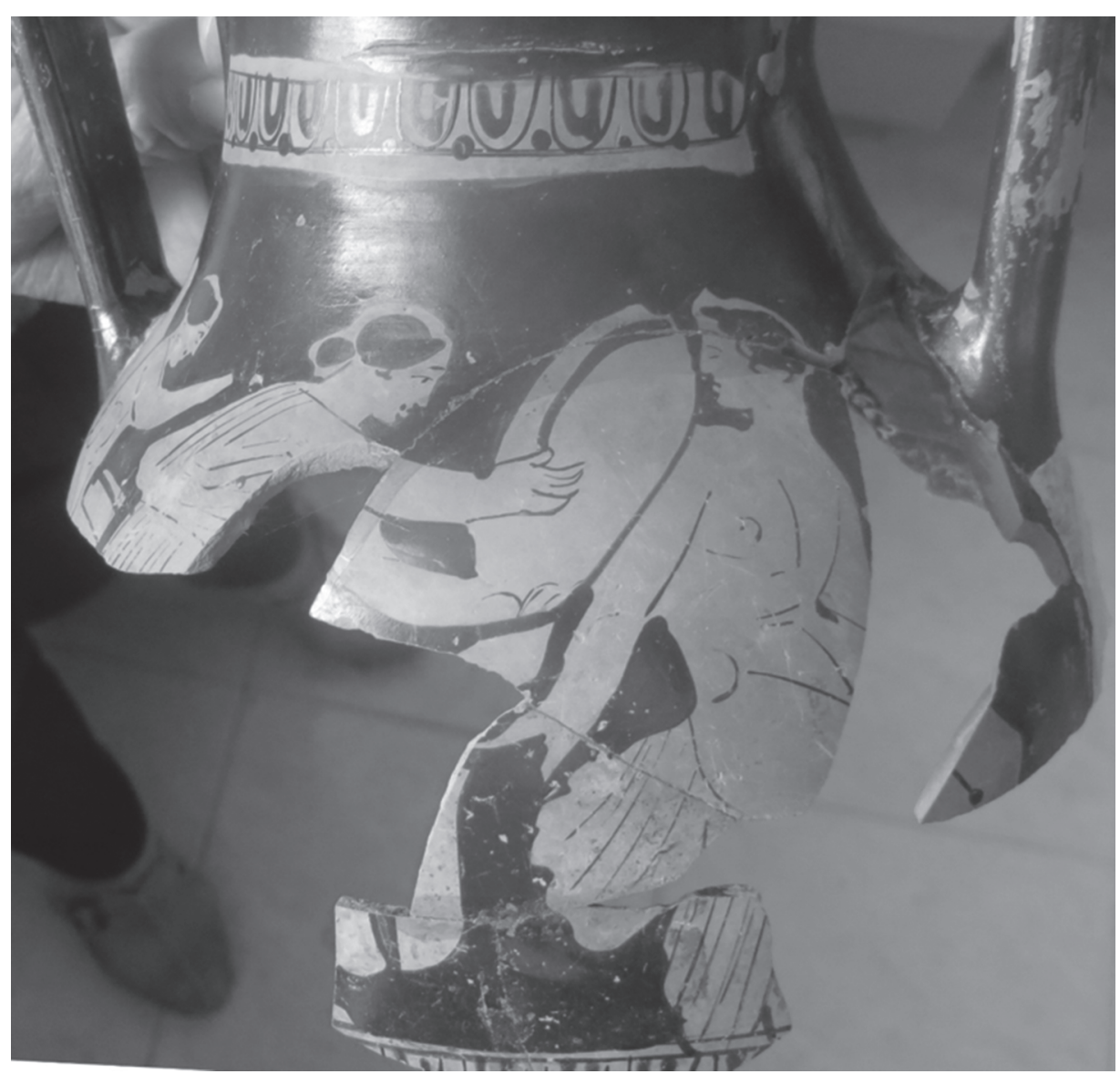

Fig. 11. Rhea and Kronos, scene on Attic hydria, the late 4th century BC

its final destruction by the Celts in $279 \mathrm{BC}$ : it was first destroyed in the eighties of the $4^{\text {th }}$ century BC, kept its autonomy under Thracian rulers and even after the conquest of Thrace by Philip II, which left here only little damage. It was the last harbour on the Hebros and centre of trade on the Thracian plain with supervised market colonnade also at the Eastern Gate where carts arriving from south, southwest and north unloaded and loaded their goods. Pistiros had several workshops of bronze- and ironsmiths, mines of iron, copper and gold in the vicinity and enough timber. Its kilns produced fine pottery and tiles and some role of slave trade can also be supposed (cf. for the functional analysis Bouzek 2016b). Slightly similarly sounding Masteira mentioned by Demosth. Orat. VIII (De Chers.), 44; X (Philip. IV), 15 and which some scholars tried to be identified with Pistiros, was described by him in bright colours; the air of the seals and the pelike may have been part of the atmosphere in the emporion. 


\section{REFERENCES}

AGDS I/1 = E. Brandt, Antike Gemmen in deutschen Sammlungen I. Staatliche Münzsammlung München 1. Griechische Gemmen von minoischer Zeit bis zum späten Hellenismus. München: Prestel Verlag, 1968. AGDS I/3 = E. Brandt, A. Krug, W. Gercke, E. Schmidt, Antike Gemmen in deutschen Sammlungen I. Staatliche Münzsammlung München 1. Gemmen und Glaspasten der römischen Kaiserzeit sowie Nachträge. München: Prestel Verlag, 1972.

AGDS II = E. Zwierlein-Diehl, Antike Gemmen in deutschen Sammlungen II. Staatliche Museen Preußischer Kulturbesitz, Antikenabteilung, Berlin. München: Prestel Verlag, 1969.

AGDS IV = M. Schlüter, G. Platz-Horster, P. Zazoff, Antike Gemmen in deutschen Sammlungen IV. Hannover, Kestner Museum. Hamburg, Museum für Kunst und Gewerbe. Wiesbaden: Steiner, 1975.

Ajoutian, A., 1990. 'Hermaphroditus'. In: LIMC V, 268-283.

Akamatis, I. M., 2011. 'The Agora'. In: The Archaeological Museum of Pella. Athens: Latsis Foundation, $67-112$.

Avigad, N., 1986. Hebrew Bullae from the Time of Jeremiah: Remnants of a Burnt Archive. Jerusalem: Israel Exploration Society.

Boardman, J., 1968. Engraved Gems. The Ioanides Collection. London: Thames \& Hudson.

Boardman, J., 1970. Greek Gems and Finger Rings. London: Thames \& Hudson.

Boardman, J. [et al.], 1990. 'Heracles'. In: LIMC V, 1-192.

Boussac, M.-F., 1992. Les Sceaux de Délos 1: Sceaux publics, Apollon, Hélios, Artémis, Hécate. Paris: Ecole Française d'Athènes.

Boussac, M.-F., 1993. 'Archives personnelles à Délos'. Comptes rendus des séances de l'Académie des Inscriptions et Belles-Lettres 137, 677-693.

Bouzek, J., 1996a. 'The Bronze Appliqué and the Greek Bronzework'. In: Pistiros I, 113-114.

Bouzek, J., 1996b. 'Textile industry'. In: Pistiros I, 117-166.

Bouzek, J., 2003. 'Attic Art of $5^{\text {th }}$ and $4^{\text {th }}$ Century BC and the Art of Cimmerian Bosporus'. Studia Hercynia $7,138-153$.

Bouzek, J., 2005. Thracians and Their Neighbours: Their Destiny, Art and Heritage [= Studia Hercynia 9]. Prague: Charles University, Faculty of Arts.

Bouzek, J., 2013. 'The Czech Sector and Other Excavations: Comparative Stratigraphy and Chronology'. In: Pistiros V, 66-69.

Bouzek, J., 2015. 'New Contributions to Black Sea Iconography'. Ancient West and East 14, 237-252.

Bouzek, J., 2016a. 'A Magical Loom-Weight and the Mother of Gods in Thrace'. Ancient West and East $15,2016,103-112$.

Bouzek, J., 2016b. 'The Emporion of Pistiros: Hippodamean Foundation and Market Place'. In: M. Manoledakis (ed.), The Black Sea in the Light of New Archaeological Data and Theoretical Approaches. Proceedings of the $2^{\text {nd }}$ International Workshop on the Black Sea in Antiquity Held in Thessaloniki, 18-20 September 2015. Oxford: Archaeopress, 89-98.

Bouzek, J., Domaradzka, L., 2013. 'Emporion Pistiros between Greater Powers: 450-278 B.C. An Attempt to Sketch Its History'. Studia Hercynia 17/1, 28-35.

Bouzek, J., Ondřejová, I., 2015. 'Dancing Maenads and Satyr on Sealings from the Time of Philip II and Alexander the Great at Pistiros'. Eirene 51, 269-277.

Domaradzka, L., 2013. 'Newly Discovered Graffiti from Pistiros (2004-2010)’. In: Pistiros V, 198-206.

Domaradzki, M., 1996. 'Interim Report on Archaeological Investigations at Vetren-Pistiros, 1988-94'. In: Pistiros I, 13-34.

Domaradzki, M., 2002. 'La production de fibules à Pistiros'. In: Pistiros II, 249-254.

Furtwängler, A., 1896. Beschreibung der geschnittenen Steine im Antiquarium. Königliche Museen zu Berlin. Berlin: W. Spemann.

Furtwängler, A., 1900. Die antiken Gemmen. Geschichte der Steinschneidekunst im klassischen Altertum. Leipzig / Berlin: Giesecke \& Devrient.

Gates, J. E., 2003. 'A Clay Sealing from Karanis in the Kelsey Museum'. Bulletin. The University of Michigan, Museums of Art and Archaeology 15, 92-95. http://hdl.handle.net/2027/spo.0054307.0015.106 [26 February 2017]. 
Gotzev, A., Petrova, V., 2013a. 'Archaeological Investigations in Square B 23 and B' 3 in 2012'. In: Pistiros V, 191-194.

Gotzev, A., Petrova, V., 2013b. 'Catalogue of Sealings Found in Square B' 3'. In: Pistiros V, 195-198.

Gury, K., 1994. 'Rhea'. In: LIMC VII, 628-632.

Henig, M., 2007. A Corpus of Roman Engraved Gemstones from British Sites [= British Archaeological Reports. British Series 8]. London: Bristol Classical Press.

Herbert, Sh. C., 2003. 'The Hellenistic Archives from Tel Kedesh (Israel) and Seleucia-on-the-Tigris (Iraq)'. Bulletin. The University of Michigan, Museums of Art and Archaeology 15, 65-86. http://hdl .handle.net/2027/spo.0054307.0015.104 [26 February 2017].

Lazov, G., 1996. 'Bronze Appliqué from Pistiros'. In: Pistiros I, 109-112.

LIMC = Lexicon Iconographicum Mythologiae Classicae. I-IX. Zurich / Munich / Düsseldorf: Artemis \& Winkler Verlag, 1981-2009.

Maaskant-Kleibrink, M., 1978. Catalogue of the Engraved Gems in the Royal Coin Cabinet, the Hague: the Greek, Etruscan, and Roman Collections. The Hague: Goverment Publishing Office / Wiesbaden: Steiner.

Nankov, E., 2008. 'The Fortification of the Early Hellenistic Thracian City of Seuthopolis: Breaking the Mold'. Archaeologia Bulgarica 12/3, 15-56.

Nankov, E, 2012. 'Beyond Hellenisation. Reconsidering the Situation in the Thracian City of Seuthopolis’. In: M. Manov (ed.), Vasilka Gerasimova-Tomova in memoriam. Sofia: National Institute of Archaeology, 109-126.

Ondřejová, I., 2007. 'Gem Imprints on Loom-Weights: the Running Dog'. In: Pistiros III, 243-246.

Pipili, M. 1990. 'Iolaos'. In: LIMC V, 686-696.

Pistiros = J. Bouzek [et al.] (eds.), Pistiros. Excavations and Studies. I-VI. Prague: Charles University, Faculty of Arts, 1996-2016.

Plantzos, D., 1999. Hellenistic Engraved Gems. Oxford: Clarendon Press.

Platz-Horster, G., 1987. Die antiken Gemmen aus Xanten. Köln: Rheinland Verlag / Bonn: Habelt.

Richter, G. M. A., 1968. Engraved Gems of the Greeks, Etruscans and Romans. Part I: Engraved Gems of the Greeks and Etruscans. London: Phaidon Press Limited.

Rolle, R., Müller-Wille, M., Schietzel, K. (eds.), 1991. Gold der Steppe. Archäologie der Ukraine. Schlesswig: Archäologisches Landesmuseum.

Serbeti, E. D., 1992. 'Kronos'. In: LIMC VI, 142-147.

Stamboulidis, N., 1992. Les sceaux de Délos 2: O erotikos kyklos. Paris: Ecole Française d'Athènes.

Velkov, V., Domaradzka, L., 1996. 'Kotys I (383/359 B. C.) and Emporion Pistiros'. In: Pistiros I, 205-216.

\section{LIST OF FIGURES (THE PISTIROS ARCHIVES)}

Fig. 1. Pistiros. Destruction of the kiln (oven) in Square B' 3, ca. 310 BC.

Fig. 2. Two warriors or Heracles and Iolaos with Hydra, sealing 4.

Fig. 3. Hermaphrodite, sealing 5.

Fig. 4. Hermaphrodite, sealing $6 \mathrm{~b}$.

Fig. 5. Comic actor, sealing $12 \mathrm{~b}$.

Fig. 6. Comic actor, bronze appliqué of a throne.

Figs. 7-9. Mice with astragals, sealing 1a.

Fig. 10. Loom-weights with impressions: running dog.

Fig. 11. Rhea and Kronos, scene on Attic hydria, the late $4^{\text {th }}$ century BC. 


\title{
GROTESKNO, KARIKATURY A CHYTRÉ MYŠI V PISTIRU
}

Článek se zabývá pěti zvláštními exempláři z 27 pečetí nalezenými v bulharském Pistiru v roce 2012. Většina má otisk z obou stran a zřejmě byly připojeny ke smlouvě nebo dohodě. Výjevy zobrazené na pečetích, které jsou zde probírány, jsou komické, mají charakter karikatury a zobrazují i myši, které se chovají jako lidé. Jsou odrazem specificky anekdotické stránky řeckého umění na jeho severní periferii v době Filippa II. a Alexandra Velikého. Připojena je attická peliké z pozdního 4. stol. př. n. l. nalezená v Pistiru s podobnou karikaturou Rhey a Krona, uchovávaná v Pistiru jako památeční předmět až do jeho zničení kolem roku 310 př. n. 1 .

\author{
Jan Bouzek \\ Charles University, Prague \\ jan.bouzek@ff.cuni.cz \\ Iva Ondřejová † \\ Charles University, Prague
}

